\title{
RESPON FISIOLOGIS DOMBA EKOR TIPIS DAN GARUT DENGAN PEMBERIAN PAKAN KONSENTRAT DAN LIMBAH TAUGE
}

\section{The Physiological Response of Javanese Thin Tailed Sheep and Garut Sheep Fed By Concentrate and Mung Bean Sprout Waste Diet}

\author{
Listya Purnamasari1, Syeh Ahmad Muhammad Basalamah², Sri Rahayu², \\ dan Sri Darwati ${ }^{2}$ \\ 1 Program Studi Peternakan, Fakultas Pertanian, Universitas Jember \\ 2Departemen Teknologi Produksi Ternak, Fakultas Pertanian, IPB University \\ Email: listyap.faperta@unej.ac.id
}

\begin{abstract}
ABSTRAK
Penelitian ini bertujuan untuk mengetahui respon fisiologis Domba ekor tipis (DET) dan domba Garut yang diberi pakan konsentrat dan limbah tauge. Variabel yang diamati yaitu suhu rektal, laju respirasi dan denyut jantung domba. Sebanyak 6 ekor DET (bobot badan 16,27 $\pm 0,86 \mathrm{~kg}$ ) dan 6 ekor domba Garut (bobot badan 10,68 $\pm 1,82 \mathrm{~kg}$ ) berumur kurang dari satu tahun dipilih untuk diuji menggunakan 4 perlakuan pola faktorial $2 \times 2$ dengan faktor pertama yaitu pemberian pakan (konsentrat dan limbah tauge) dan bangsa ternak (DET dan domba Garut). Semua domba diberi pakan sesuai kebutuhan hidup berdasar bobot badan. Suhu lingkungan dan respon fisiologis diukur pada ternak setiap pagi sebelum pemberian pakan selama 8 minggu. Hasil analisis menunjukkan respon fisiologis DET dan domba Garut dengan perlakuan pakan konsentrat dan limbah tauge tidak menunjukkan adanya interaksi. Jenis domba tidak berbeda nyata $(\mathrm{P}>0,05)$ namun perlakuan pakan berpengaruh nyata terhadap respon fisiologis $(\mathrm{P}<0,05)$. Suhu rektal, denyut jantung dan laju respirasi masih tergolong normal sehingga pakan limbah tauge dapat dijadikan alternatif sumber protein pengganti konsentrat.
\end{abstract}

Kata kunci: DET, Domba Garut, Limbah Tauge, Respon Fisiologis

\begin{abstract}
The present study aimed to evaluate some physiological variables of thin tailed sheep and Garut sheep fed by concentrate and mung bean sprout waste diet. The physiological variables included rectal temperature, respiration rate, and heart rate. Six Javanese thin tailed sheeps $(16.27 \pm 0.86$ $\mathrm{kg}$ ) and six Garut sheeps (10.68 $\pm 1.82 \mathrm{~kg})$ which aged less a year were selected for 4 treatments by factorial design $2 \times 2$. The first factor was diet (concentrate and bean sprout waste) and the second factor was kind of sheep (Javanese thin tailed sheep and Garut sheep). The sheep were fed individually for a maintenance requirement on body weight. Ambient temperature, relative humidity, and physiological variables were measured every morning before feeding during 8 weeks. The result showed that the physiological response of Javanese thin tailed sheep and Garut sheep fed by concentrate and mung bean sprout waste diet showed no interaction $(P>0.05)$. The physiological response of sheep was not significantly different but the feed treatments had a significant effect $(P>0.05)$. Rectal temperature, heart rate, and respiration rate were still classified as normal so the mung bean sprout waste diet can be used as an alternative source of protein to substitute concentrate.
\end{abstract}

Keywords: Garut Sheep, Javanese Thin Tailed Sheep, Mung Bean Sprout Waste, Physiologycal Response

\section{PENDAHULUAN}

Domba merupakan salah satu ternak penghasil daging yang banyak dibudidayakan di Indonesia, memiliki sifat prolifik yaitu beranak lebih dari satu per kebuntingan dan mudah beradaptasi (Purnamasari et al., 2018). Mamalia berdarah panas ini, banyak dijumpai 
di wilayah tropis, memiliki daya adaptasi tinggi (Cwinar, 2014) yang memiliki kemampuan mempertahankan suhu tubuhnya pada kisaran tertentu. Jenis domba yang banyak dibudidayakan di Indonesia yaitu DET dan domba Garut. Faktor lingkungan seperti pakan, manajemen pemeliharaan, dan iklim berpengaruh terhadap produkivitas ternak. Suhu lingkungan yang tidak tepat dapat mengganggu produktivitas ternak. Selain itu, kelembapan dan suhu yang tinggi mengakibatkan timbulnya cekaman pada ternak domba lokal yang dapat dilihat dari meningkatnya respon fisiologis seperti suhu rektal, denyut jantung dan laju pernafasan.

Faktor pakan merupakan komponen penting dalam suatu usaha penggemukan domba. Pakan juga merupakan salah satu faktor penentu dalam meningkatkan produktivitas ternak dengan memperhatikan kandungan nutrien dan ketersediannya sehingga perlu dipertimbangan kualitas dan kuantitasnya. Rumput dan leguminosa merupakan pakan utama ternak yang mengandung serat kasar. Pemberian pakan penguat atau konsentrat biasanya digunakan untuk meningkatkan produktivitas ternak. Menurut Mulyaningsih (2006), pemberian pakan hijauan yang ditambah konsentrat dapat menghasilkan pertumbuhan dan perkembangan domba yang baik. Limbah pertanian dan industri berpotensi digunakan sebagai pakan lokal ternak yaitu limbah tauge.

Limbah tauge merupakan salah satu limbah pertanian yang dapat menjadi pilihan alternatif pakan penguat dengan kandungan nutrien yang menyerupai konsentrat yaitu protein kasar 13,63\%, serat kasar 49,44\%, abu 7,35\%, lemak kasar 1,16\% dan TDN $64,65 \%$. Limbah tauge mampu menggantikan rumput dan tidak mengganggu fisiologis ternak (Purnamasari et al., 2018). Pemberian pakan yang kurang tepat juga dapat mempengaruhi reaksi sistem hidup ternak yang biasa dikenal dengan istilah respon fisiologis. Faktor suhu dan kelembaban lingkungan yang tinggi mempengaruhi konsumsi pakan sebagai salah satu cara untuk mengurangi beban panas (Bhatta et a.l, 2006) dan menurunkan produktivitas ternak karena banyak energi yang dibutuhkan untuk menstabilkan suhu tubuh (Panagakis, 2011) serta berdampak pada respon fisiologis domba sebagai indikator adanya stress panas (Salsabila et al., 2014).

Penelitian ini mengkaji tentang pemberian alternatif pakan penguat atau konsentrat berupa limbah tauge yang diharapkan dapat meningkatkan produktivitas ternak namun tidak mengganggu respon fisiologis ternak. Tujuan dari penelitian ini yaitu membuktikan pengaruh pemberian limbah tauge sebagai pakan penguat terhadap respon fisiologis DET dan domba Garut.

\section{METODE}

Penelitian dilakukan di laboratorium lapang bagian Ilmu Produksi Ternak Ruminansia Kecil Blok B, Departemen Ilmu Produksi dan Teknologi Peternakan, Fakultas Peternakan, Institut Pertanian Bogor.

\section{Alat dan Bahan}

Peralatan yang digunakan yaitu kandang individu berukuran $0,9 \times 0,9 \times 1 \mathrm{~m}$ yang dilengkapi tempat pakan dan tempat minum. Alat yang digunakan dalam proses pengambilan data yaitu thermometer digital GP Care $0,1^{\circ} \mathrm{C}$, thermometer bola basah dan kering, stopwatch SEIKO, stetoskop OneMed, timbangan gantung WeiHeng dengan kapasitas $50 \mathrm{~kg}$ ketelitian 0,01 gram, timbangan duduk SM dengan kapasitas $5 \mathrm{~kg}$ ketelitian $10 \mathrm{~g}$, terpal, gunting, dan alat tulis. Ternak yang digunakan sebanyak 12 ekor domba jantan berumur 6 sampai 10 bulan $\left(\mathrm{I}_{0}\right)$ yang terdiri dari 6 ekor DET (bobot badan $16,27 \pm 0,86 \mathrm{~kg}$ ) dan 6 ekor domba garut (bobot badan 10,68 $\pm 1,82 \mathrm{~kg}$ ).

Rancangan percobaan yang digunakan yaitu rancangan acak lengkap pola faktorial $2 \times 2$ dengan faktor pertama pemberian pakan (konsentrat dan limbah tauge) dan faktor kedua yaitu jenis ternak (DET dan domba 
Garut). Perlakuan yang digunakan dapat dilihat pada Tabel 1. Pakan yang digunakan yaitu rumput lapang, konsentrat dan limbah tauge. Kandungan nutrient bahan pakan perlakuan dapat dilihat pada Tabel 2. kondisi bahan pakan dapat dilihat pada gambar 1 .

Tabel 1. Perlakuan Pemberian Pakan Limbah Tauge dan Konsentrat yang Digunakan

\begin{tabular}{lcc}
\hline \multicolumn{1}{c}{ Perlakuan } & DET (A1) & Domba Garut (A2) \\
\hline Konsentrat (P0) & P0A1 & P0A2 \\
Limbah Tauge (P1) & P1A1 & P1A2 \\
\hline
\end{tabular}

Tabel 2. Kandungan Nutrien Bahan Pakan Berdasar Bahan Kering

\begin{tabular}{lccccccc}
\hline Pakan & BK & Abu & PK & SK & LK & Beta-N & TDN (\%) \\
& $(\%)$ & $(\%)$ & $(\%)$ & $(\%)$ & $(\%)$ & $(\%)$ & \\
\hline Rumput 1) & 19,81 & 5,65 & 8,73 & 29,13 & 1,92 & 54,57 & 59,35 \\
Konsentrat 2$)_{\text {Limba Tauge }^{3)}}$ & 80,52 & 14,11 & 13,14 & 16,92 & 5,97 & 49,86 & 62,11 \\
P0 & 36,65 & 7,53 & 13,63 & 49,44 & 1,17 & 28,42 & 64,65 \\
P1 & 50,17 & 9,88 & 10,94 & 23,02 & 3,94 & 52,22 & 60,69 \\
\hline
\end{tabular}

Keterangan : 1) Pusat Antar Universitas IPB (2013); 2) Wandito (2011); ${ }^{3)}$ Rahayu et al. (2010). BK = bahan kering; $\mathrm{PK}=$ protein kasar; $\mathrm{SK}=$ serat kasar; $\mathrm{LK}=$ lemak kasar; $\mathrm{TDN}=$ total digestible nutrient. $\mathrm{P0}=50 \%$ rumput lapang $+50 \%$ konsentrat, $\mathrm{P} 1=50 \%$ rumput lapang $+50 \%$ limbah tauge.
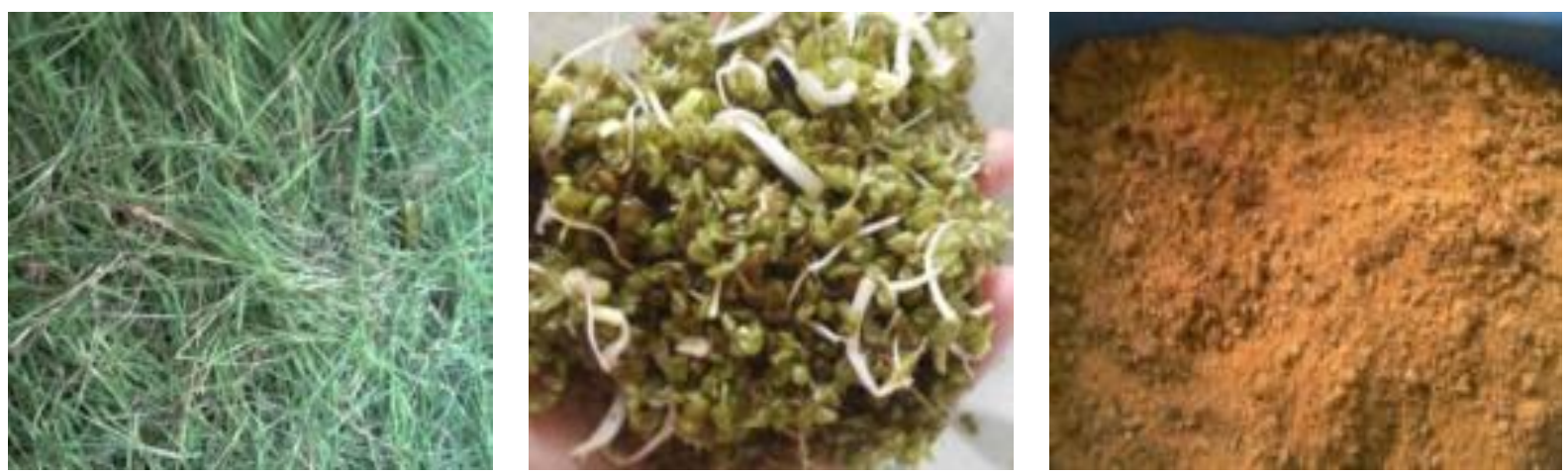

Gambar 1. Kondisi bahan pakan sebelum dihomogenisasi rumput lapang limbah tauge dan konsentrat.

Parameter yang diamati yaitu denyut jantung, suhu rektal, dan laju respirasi. Semua parameter diamati setiap pagi sebelum pemberian pakan yaitu pada pukul 06.00 WIB selama 8 minggu. Setiap pengamatan dilakukan dengan waktu selama 60 detik. Pakan diberikan berdasarkan perhitungan 4\% bobot badan per hari, dilakukan sebanyak 2 kali sehari pada pagi pukul 07.00 WIB dan sore pukul 16.00 WIB, serta air minum diberikan secara ad libitum. Data yang diperoleh dianalisis menggunakan ANOVA (Analysis of Variance) menggunakan software Minitab 16 dan dilanjutkan dengan uji Tukey.

\section{HASIL DAN PEMBAHASAN}

Salah satu faktor yang mempengaruhi pertumbuhan ternak adalah faktor lingkungan. Pemeliharaan dilakukan di kandang individu model paggung sehingga kotoran ternak bisa jatuh ke bagian bawah dan kandang memiliki langit-langit atap tipe tertutup dengan bahan asbes serta memiliki ventilasi pada bagian sisi depan, belakang, kanan dan kiri kandang. Ventilasi bagian belakang kandang berhadapan langsung dengan lapangan pastura dimana angin bertiup cukup kencang pada pagi hingga sore, 
sedangkan pada malam hari ditutup dengan terpal.

Kondisi lingkungan selama penelitian baik suhu maupun kelembaban lingkungan disajikan pada Tabel 3. Pengukuran suhu dan kelembaban kandang diukur setiap hari pada pagi pukul 07.30 WIB, siang pukul 13.30 dan sore 17.30 .

Tabel 3. Rataan Suhu dan Kelembaban Udara di Lokasi Kandang Penelitian

\begin{tabular}{lccc}
\hline \multicolumn{1}{c}{ Waktu } & $\begin{array}{c}\text { Suhu di luar kandang } \\
\left({ }^{\circ} \mathrm{C}\right)\end{array}$ & $\begin{array}{c}\text { Suhu di dalam kandang } \\
\left({ }^{\circ} \mathrm{C}\right)\end{array}$ & $\begin{array}{c}\text { Kelembaban udara di } \\
\text { dalam kandang }(\%)\end{array}$ \\
\hline Pagi & $24,27 \pm 1,08$ & $22,23 \pm 1,75$ & $91,26 \pm 1,24$ \\
Siang & $29,13 \pm 2,95$ & $31,28 \pm 2,12$ & $86,75 \pm 3,59$ \\
Sore & $26,34 \pm 1,37$ & $28,50 \pm 1,01$ & $89,33 \pm 3,89$ \\
\hline
\end{tabular}

Beberapa unsur mikro yang dapat mempengaruhi produktivitas secara langsung ada 4 unsur yaitu kecepatan angin, radiasi, suhu dan kelembaban udara yang memiliki indeks dengan pengaruh yang berbeda terhadap ternak (Yani dan Purwanto, 2006). Suhu udara pada saat penelitian rendah pada pagi hari, meningkat pada siang hari dan menurun kembali pada sore hari. Menurut Kartasudjana (2001) suhu optimal bagi ternak di daerah tropis yaitu 22 sampai $31^{\circ} \mathrm{C}$ sedangkan Yani dan Purwanto (2006) suhu pada daerah tropis berkisar antara 24 sampai $34^{\circ} \mathrm{C}$ dengan kelembaban 60 sampai $90 \%$ sehingga pada penelitian ini masih tergolong normal. Suhu dan kelembapan di sekitar kandang dipengaruhi oleh kondisi cuaca selama penelitian yaitu musim hujan.

\section{Respon Fisiologis Ternak}

Penelitian dimulai dengan masa adaptasi selama 2 minggu. Selama masa adaptasi, ternak diberi obat cacing, vitamin dan obat tetes mata. Pada masa adaptasi ini, beberapa DET mengalami sakit orf atau radang di sekitar mulut yang menyebabkan terjadinya penurunan konsumsi pakan. Selama penelitian berlangsung beberapa domba juga mengalami gangguan kesehatan seperti sakit mata (30\%), diare (25\%), kembung atau bloat (20\%) dan orf (20\%). Adanya domba yang sakit mata dialami oleh ternak dengan perlakuan 0 (P0) yang diberi paka berupa konsentrat yang berbentuk tepung/mash. Bentuk konsentrat ini yang diduga menimbulkan debu yang kemudian masuk ke mata. Penyakit orf, diare, dan kembung diduga karena pemberian rumput lapang yang kurang dilayukan dan masih dalam keadaan basah karena pengambilan rumput pagi hari dan seringnya terjadi hujan.

Respon fisiologis mempengaruhi kondisi dalam tubuh ternak yang berkaitan dengan faktor cuaca, nutrisi, dan manajemen pemeliharaan (Awabien, 2007). Dijelaskan juga oleh Isnaeni (2006) bahwa adanya perubahan yang terjadi pada lingkungan tempat hidup ternak mempengaruhi reaksi sistem hidup ternak yang biasa dikenal dengan istilah respon fisiologis. Respon fisiologis yang diukur dalam penelitian ini yaitu suhu rektal, denyut jantung dan laju respirasi. Rataan respon fisiologis pada domba selama penelitian dapat dilihat pada Tabel 4.

Hasil penelitian menunjukkan bahwa tidak ada interaksi antara pemberian pakan dan jenis ternak. Perbedaan jenis domba tidak berbeda nyata terhadap respon fisiologis ternak sedangkan berdasar pemberian pakan, respon fisiologis berpengaruh nyata $(\mathrm{P}<0,05)$. Suhu rektal, denyut jantung, dan laju respirasi domba baik DET maupun Domba Garut yang diberi pakan P0 lebih tinggi daripada pakan P1. Hal ini diduga karena kandungan air pakan P1 yang mengandung limbah tauge lebih tinggi daripada pakan P0 dengan konsentrat sehingga kandungan air ini dapat mengimbangi peningkatan panas yang dihasilkan oleh tubuh ternak. 
Menurut Mugendi et al. (2010) dan Shah et al. (2011) kandungan vitamin C (asam askorbat) dalam limbah tauge dapat mengurangi tingkat stress domba sehingga berpengaruh juga pada respon fisiologis ternak. Suhu rektal, denyut jantung dan laju respirasi ternak memiliki keterkaitan satu dengan yang lain. Apabila suhu tubuh mengalami peningkatan maka denyut jantung akan mengalami pulsus dan laju respirasi akan lebih cepat (Isnaeni, 2006).

\section{Suhu Rektal}

Suhu tubuh dapat diukur melalui suhu rektal. Menurut Marai et al. (2007) suhu rektal dapat digunakan sebagai ukuran representatif suhu tubuh sehingga dapat dijadikan sebagai parameter yang menunjukkan bahwa adanya cekaman lingkungan terhadap domba. Rensis dan Scaramuzzi (2003) yang menyatakan bahwa keseimbangan termal tubuh ternak dapat dilihat dari indikator suhu rektal. Suhu rektal Domba ekor tipis dan domba Garut yang diberi pakan P0 lebih tinggi dibandingkan dengan pakan P1.

Perbedaan suhu ini diduga disebabkan oleh kandungan energi pada pakan P0 yang lebih rendah $(60,69 \%)$ dibandingkan dengan pakan P1 (63,25\%). Suhu rektal pada penelitian ini antara 38,51 sampai $38,91^{\circ} \mathrm{C}$ yang masih tergolong normal seperti yang disampaikan oleh Smith dan Mangkuwidjodo (1988) yaitu 38,5 sampai $40^{\circ} \mathrm{C}$; menurut Gonzaga do Santos et al. (2019) yaitu 38,5 sampai $39,7^{\circ} \mathrm{C}$; dan menurut Marai et al. (2007) yaitu 38,3 sampai $39,9^{\circ} \mathrm{C}$.

Tabel 4. Rataan Respon Fisiologis DET dan Garut yang Diberi Pakan Limbah Tauge dan Konsentrat Selama Penelitian

\begin{tabular}{lclll}
\hline \multirow{2}{*}{ Jenis Domba } & $\begin{array}{c}\text { Perlakuan } \\
\text { Pakan }\end{array}$ & Suhu Rektal $\left({ }^{\circ} \mathrm{C}\right)$ & $\begin{array}{c}\text { Denyut Jantung } \\
\text { (kali/menit) }\end{array}$ & $\begin{array}{c}\text { Laju Respirasi } \\
\text { (hembusan/menit) }\end{array}$ \\
\cline { 3 - 5 } DET & P0 & $38,91 \pm 0,40^{\mathrm{a}}$ & $81,25 \pm 7,59^{\mathrm{a}}$ & $26,44 \pm 3,94^{\mathrm{a}}$ \\
& P1 & $38,56 \pm 0,33^{\mathrm{bc}}$ & $69,81 \pm 4,48^{\mathrm{ab}}$ & $22,25 \pm 2,18^{\mathrm{b}}$ \\
\hline Domba Garut & P0 & $38,86 \pm 0,38^{\mathrm{ab}}$ & $76,50 \pm 9,78^{\mathrm{ab}}$ & $23,28 \pm 4,20^{\mathrm{ab}}$ \\
& P1 & $38,53 \pm 0,24^{\mathrm{c}}$ & $67,42 \pm 8,92^{\mathrm{b}}$ & $21,75 \pm 3,51^{\mathrm{b}}$ \\
\hline
\end{tabular}

Keterangan: Angka-angka pada kolom yang sama yang diikuti oleh huruf yang berbeda menunjukkan berbeda nyata pada taraf uji 5\% ( $\mathrm{P}<0.05) ; \mathrm{P} 0=50 \%$ rumput lapang $+50 \%$ konsentrat; $\mathrm{P} 1=50 \%$ rumput lapang $+50 \%$ limbah tauge

\section{Denyut Jantung}

Denyut jantung domba yang diberi pakan P0 lebih tinggi dibandingkan dengan pakan P1. Denyut jantung masih dalam kisaran normal sesuai pendapat Duke (1995) yaitu 60 sampai 120 kali per menit. Penelitian Purnamasari et al. (2018) juga menyatakan bahwa DET yang diberi pakan limbah tauge dan kangkung kering memiliki denyut jantung rata-rata $73,58 \mathrm{kali} / \mathrm{menit}$.

Tingginya denyut jantung pada domba ekor tipis dan domba Garut yang diberi pakan P0 diduga disebabkan oleh pakan P1 yang mengandung limbah tauge serta memiliki kadar air lebih tinggi dibandingkan dengan pakan P0 seperti terlihat pada Tabel 2 . Kandungan air dalam limbah tauge ini dapat mengimbangi panas yang berasal dari metabolisme dalam tubuh ternak. Selain itu limbah tauge juga mengandung vitamin $\mathrm{C}$ (asam askorbat) yang dapat mengurangi stres pada ternak domba (Mugendi et al, 2010 dan Shah et al., 2011). Menurut Nikkhan et al. (2008) peningkatan denyut jantung dipengaruhi oleh meningkatnya suhu darah dan penurunan tekanan darah dari vasolidatasi peripheral. Peningkatan denyut jantung dapat menjaga tekanan darah menjadi stabil akibat dilatasi pembuluh darah (Isnaeni, 2006). 


\section{Laju Respirasi}

Respirasi pada ternak bertujuan untuk memenuhi kebutuhan oksigen melalui proses pertukaran gas. Laju respirasi erat kaitannya dengan termoregulasi dalam tubuh ternak untuk pengeluaran panas yaitu sekitar 20\% (Marai et al. 2007). Laju respirasi normal pada domba berkisar antara 26 sampai 32 kali/menit (Frandson, 1992). Menurut Silanikove (2000) tingkat stres berpengaruh pada laju respirasi dimana domba yang mengalami stres ringan memiliki laju respirasi 40 sampai $60 \mathrm{kali} / \mathrm{menit}$, stres panas tinggi yaitu 80 sampai $200 \mathrm{kali} /$ menit sedangkan stres panas berat yaitu $200 \mathrm{kali} / \mathrm{menit}$.

Penelitian ini laju respirasi dipengaruhi $(\mathrm{P}<0,05)$ oleh pemberian pakan. Domba yang diberi pakan P0 memiliki laju respirasi yang lebih tinggi dibandingkan pakan P1. Hal ini diduga karena pemberian konsentrat dalam bentuk tepung kering secara tidak langsung meningkatkan metabolisme tubuh sehingga laju pernafasan cenderung lebih tinggi untuk membuang panas tubuh (Kirjin et al. 2020). Bentuk fisik pakan konsentrat ini juga menyebabkan waktu tinggal dalam rumen menjadi lebih cepat sehingga mikroba rumen kurang bisa mencerna dengan baik, kurang efisien, dan kurang disukai ternak (Budiman et al. 2006).

\section{KESIMPULAN}

Perbedaan jenis domba ternyata tidak memberikan pengaruh interaksi terhadap kondisi respon fisiologis. Pemberian pakan konsentrat memiliki nilai respon fisiologis antara lain suhu rektal, denyut nadi, dan laju respirasi yang lebih tinggi dibandingkan pemberian pakan limbah tauge. Respon fisiologis masih dalam keadaan normal walaupun di awal penelitian beberapa ekor ternak mengalami sakit mata, orf, dan diare serta tidak mengindikasikan stres ternak, Pakan alternatif limbah tauge dapat digunakan sebagai pakan penguat.

\section{DAFTAR PUSTAKA}

Awabien, R.L. 2007. Respon fisiologis domba yang diberi minyak ikan dalam bentuk sabun kalsium. Skripsi. Institut Pertanian Bogor. Bogor.

Badan Meteorologi Klimatologi dan Geofisika. 2013. Data cuaca, kelembaban dan curah hujan wilayah Darmaga Bogor. Bogor.

Bhatta, R., V. Kumar, M. Sridhar, and K. Singh. 2006. Energy expenditure in crossbred cattle fed paddy straw of different form. Asian-Australasian Journal of Animal Sciences. 19:1755-1760.

Budiman, A., T. Dhalika, dan B. Ayuningsih. 2006. Uji kecernaan serat kasar dan bahan ekstrak tanpa nitrogen (BETN) dalan ransum lengkap berbasis hijauan daun pucuk tebu (Saccharum officinarum). Jurnal Ilmu Ternak Universitas Padjadjaran. 6(2):132-135.

Cwynar, P., R. Kolacz, and A. Czerki. 2014. Effect of heat stress on physiological parameters and blood composition in Polish Merino rams. Berliner und Münchener Tierärztliche Wochenschrift 127:177-182.

Duke, N.H. 1995. The Physiology of Domestic Animal. Comstock Publishing. New York.

Frandson RD. 1992. Anatomi dan Fisiologi Ternak. Gadjah Mada University Press. Yogyakarta.

Gonzaga do Santos, A.C., A. Yamin, R. Priyanto, dan H. Maheswari. 2019. Respon fisiologis domba pada system pemeliharaan dan pemberian jenis konsentrat berbeda. Jurnal Ilmu Produksi dan Teknologi Hasil Peternakan. 7(1):1-9.

Isnaeni, W. 2006. Fisiologi Hewan. Kanisius. Jakarta.

Kartasudjana, R. 2001. Proses Pemotongan Ternak di RPH. Departemen Pendidikan Nasional. Jakarta.

Kirjin, M.A.H., S. Rahayu, dan M. Baihaqi. 2020. Respon Fisiologis Domba Lokal dengan Frekuensi Pemberian Pakan dan Taraf Konsentrat Limbah Ulat Hongkong (Tenebrio molitor) yang Berbrda. Jurnal Ilmu Produksi dan Teknologi Hasil Peternakan. 8(1):48-53. 
Marai, I.F.M., A.A. El-Darawany, A. Fadiel, and M.A.M. Abdel-Hafez. 2007. Physiological traits as affected by heat stress in sheep. Small Ruminant Research. 71:1-12.

Mugendi, J.B., E.N.M. Njagi, E.N. Kuria, M.A. Mwasaru, J.G. Mureithi, and Z. Apostolides. 2010. Effects of processing technique on the nutritional composition and anti- nutrient content of mucuna bean (Mucuna pruriens L.). Afr. Journal of Food Science. 4(4):156166.

Mulyaningsih, T. 2006. Penampilan DET jantan yang digemukkan dengan beberapa imbangan konsentrat dan rumput gajah (Pennisetum purpureum). Skripsi. Institut Pertanian Bogor, Indonesia.

Nikkhan, E.N., K. Schirman, and M. Stewart. 2008. Effect of delivery time on feed intake, milk productin and blood metabolites of dairy cows. Journal of Dairy Science. 9:4249-4260.

Panagakis, P. 2011. Black-globe temperature effect on short-term heat stress of dairy ewes housed under hot weather conditions. Small Ruminant Research. 100:96-99.

Purnamasari, L., S. Rahayu. dan M. Baihaqi. 2018. Respon fisiologis dan palatabilitas DET terhadap limbah tauge dan kangkong kering sebagai pengganti rumput. Journal of Livestock Science and Production. 2(1): 56-63.

Pusat Antar Universitas. 2013. Hasil analisis proksimat rumput lapang. Institut Pertanian Bogor. Bogor.

Rahayu, S., D.S. Wadito, dan W.W. Ifafah. 2010. Survey Potensi Limbah Tauge di Kotamadya Bogor. Institut Pertanian Bogor. Bogor.

Rensis De, F., and R.J. Scaramuzzi. 2003. Heat stress and seasonal effects on reproduction in the dairy cow - a review. Theriogenology. 60:1139-1151.

Salsabila, S.S., S. Rahayu, dan B.W. Putra, 2014. Respon fisiologis dan tingkah laku domba garut jantan dengan pakan dan manajemen pemberian pakan berbeda. Skripsi. Institut Pertanian Bogor. Bogor.

Shah, S.A., A. Zeb, T. Masood, N. Noreen, S.J. Abbas, M. Samiullah, M.A. Alim, and A. Muhammad. 2011. Effects of sprouting time on biochemical and nutritional qualities of Mungbean varieties. Afr. J. Agric. Res. 6(22):5091-5098.

Silanikove, N. 2000. Effects of heat stress on the welfare of extensively managed domestic ruminants. Journal Livestock Production Science. 67(1-2):1-18.

Smith, J.B., dan S. Mangkoewidjojo, S. 1988. Pemeliharaan, Pembiakan dan Penggunaan Hewan Percobaan di Daerah Tropis. UI Press. Jakarta.

Wandito, D.S. 2011. Performa dan morfometrik domba ekor gemuk dengan pemberian pakan konsentrat dan limbah tauge pada taraf pemberian yang berbeda. Skripsi. Institut Pertanian Bogor. Bogor.

Yani, A. dan B.P. Purwanto. 2006. Pengaruh iklim mikro terhadap respons fisiologis sapi peranakan Fries Holland dan modifikasi lingkungan untuk meningkatkan produktivitasnya. Media Peternakan. 29(1):35-46. 